\title{
Indonesian Tweet Diplomacy - ASEAN Community in the Spotlight
}

\author{
C P Gneuss ${ }^{1}$, H H Manuela ${ }^{2}$ \\ ${ }^{1}$ Faculty of Computing and Media Universitas Bina Nusantara, Jakarta, Indonesia \\ ${ }^{2}$ Communication Officer, ASEAN Farmer's Organisation Support Programme, ASEAN \\ Foundation \\ ${ }^{1}$ cgneuss@binus.edu, ${ }^{2}$ hana.manuela@aseanfoundation.org
}

\begin{abstract}
Diplomacy in the digital era is an exciting, yet daunting task. To prevent, minimize or relieve the possibility of conflict with other countries, as well as strengthen a nation's branding, governments must match their means of communication with the emergence of new technologies that lend a cost effective and instant platform to reach the public. This paper offers an insight on the Indonesian Ministry of Foreign Affair's official twitter account @ portal_kemlu_RI and how the topic of the ASEAN community is communicated. This paper explores to which effect transformative diplomacy goals have been communicated on hand of the social media integration model and challenges of effective two-way communication through asymmetrical as well as two-way symmetrical approaches.
\end{abstract}

Keywords: Diplomacy, Communication, Public Relation

\section{INTRODUCTION}

Diplomacy in the digital era is an exciting, yet daunting task. To prevent, minimize or relieve the possibility of conflict with other countries, as well as strengthen a nation's branding, governments must match their means of communication with the emergence of new technologies that lend a cost effective and instant platform to reach the general public. In turn, the internet has made it possible for any citizen to have their critical feedback and opinions heard. The implications of an amplified public voice can make or break a country [1][2], knitting closely the link between social media, corporate and public diplomacy. Diplo Foundation, a collaboration between the governments of Malta and Switzerland are focusing on contemporary diplomacy, include within their taxonomy internet driven-changes in the fields of geo-politics, geo-economics, sovereignty and interdependence, as well as diplomatic agendas in the fields such as internet governance, cyber security and privacy.[3]

Whereas bridging the gap between the fast-paced move from traditional to digital communications platforms is a steep learning curve for most governments, Indonesia may well have an advantage being included in the top five social media markets worldwide.[4]Although there is no formal schooling in social media literacy included in Indonesian higher education curricula and whilst there is still room for improvement, [4], [5]most Indonesian diplomats will be familiar with a social media platform. The Ministry of Foreign Affairs address through 
dedicated directorates the issues of information and media, as well as multimedia and public diplomacy. Under the Ministry of Foreign Affairs, Sekolah Staf dan Pimpinan Kementerian Luar Negeri (Sesparlu) trains their senior diplomats in targeted programs to bridge traditional means of communications with digital means, such as through social media.[5]

As social media opens the gates to an affordable[6], speedy response[7] to a large audience that effective communications require, the Indonesian Ministry of Foreign Affairs has actively part-taken in social media discussions addressing Association of South East Asian Nations (ASEAN) related matters. These issues range from creating general awareness for the ASEAN community, maritime diplomacy, or address critical topics trending on Twitter[8], such as the border dispute between Indonesia and Malaysia. These types of open discussions showcase how political issues align the concept of diplomacy with public relations, by mediating "mutually beneficial relationships between organization and their publics".[9], [10]December 2015 marks the officialization of the ASEAN community. With Indonesia's commitment to ASEAN and most populous member state, Indonesia's Ministry of Foreign Affairs has a fundamental responsibility to create awareness around the ASEAN community's vision, mission and present its advantages of being part of it, to the Indonesian people.

Bar obvious economic benefits, Indonesians can also benefit from strengthened relations with ASEAN members with the opportunity to expanding Indonesians freedom of movement. [11], [12]

\section{LITERATURE REVIEW}

This section deals with theories related to research in the areas of politics, social media and public relations. The paper limits its discussion to the topic of the 'ASEAN Community', which commenced December $31^{\text {st }} 2015$.

\subsection{Public Relations Model}

There are four models of public relations by Grunig and Hunt[13], - press agentry, public information, the two-way asymmetrical model and the two-way symmetrical model. With the objective of Indonesia's Ministry of Foreign Affairs in mind, to communicate ASEAN to the general public increasingly through digital means, these four models aid in categorizing the types of communication implemented through tweets. Press agentry and public information represents one-way communication and is usually not based on formal research. Press agentry is signified by the organization's intent to persuade the audience, with possibly unethical means of manipulation or distribution of half-truths. Public information is characterized by focusing on organizational information, often in form of press releases, usually created by an in-house journalist. The two-way asymmetrical model and two-way symmetrical are, based on scientific research, reliant on two-way communication and responsive to audience feedback. The first is of persuasive nature, whereas the second focuses on transparent mitigation and conflict solving.[14]

\subsection{Social Media Integration Model}

Due to the Social Media era as a major communication medium, it is necessary to consider how the social interaction has affected the communication process. Social Media platform provide the exposure, feedback, engagement (connecting) and exchange (sharing) process that creates a major change for the traditional communication understanding. Social media 
integration theory is not only formed for digital marketing but also can be used for measuring the effectiveness of social media performance. Through the social media integration model, an individual or institutional account can maximize the usage of social media to reach theirstrategic goals.[15]

\subsection{Public Diplomacy}

The definition of public diplomacy as such, according to Ilmenau'scenter of publicdiplomacy (ICPD), is “...direct or mass-mediated communication activities by individuals, governmental and non-governmental organizations to a foreign government and/or foreign publics and/or the domestic public..." with the objective to "reduce negative clichés and prejudices, generate sympathy and understanding for its nation's ideals".[16]In order to impact on public opinion as addressed by ICPD, transformation of opinions are imperative to the contribution of public diplomacy.

Lowy Institute[17], lists key transformative goals of digital diplomacy addressing following areas:

- Knowledge management: retention, sharing and optimal use of departmental/ governmental knowledge in pursuit of national interests abroad

- Public diplomacy: connect, listens and targets important audiences and seeks to win over major online influencers

- Information management: highlights important information on policy-making and anticipates and responds to emerging social/ political movements

- Consular communications and response: focusses on direct communication channels with oversees citizens, especially targeted for situations of disaster or crisis

- Disaster response: uses connective technologies in disaster response situations

- Internet freedom: promotes freedom of speech and democracy and creates technologies to support this notion

- External resources: harness external expertise to advance national goals through the creation of digital mechanisms

- Policy planning: creating overview and foresight of internationalization and international policies

\subsection{Theoretical Framework}

According to the Public Relations Society of America (PRSA), the definition of public relation is a strategic communication where Public diplomacy can implement to shape perceptions of a country towards foreign publics.

This research focuses on how the Indonesian Ministry of Foreign Affairs promotes the ASEAN community through social media integration, based on the four public relation models necessary to support strategic asymmetrical, as well as symmetrical two-way communication.

\section{METHOD}

This research applied qualitative research through content analysis by observations of @ portal_kemlu_RI's Twitter account. December 31 ${ }^{\text {st }}, 2015$ the ten leaders of the ASEAN communities officialised a united 'ASEAN Community'. The content analysis includes all tweets addressing the ASEAN community during this period from November 2015-January 2016, a total of 135 . 
The tweets are then categorized based on the 8 transformative goals of digital diplomacy by Lowy Institute: knowledge management, public diplomacy, information management, consular communications and response, disaster response, internet freedom, external resources and policy planning. [17]. The content analysis of @ portal_kemlu_RI will also include data on impressions, engagement and re-tweets to draw correlations to the social media integration theory-model.

Additionally, an interview is conducted with Mrs. Siti Sofia Sudarma, director of information and media of the Ministry of Foreign Affairs to address the actual objectives of the Ministry of Foreign Affairs of the Republic of Indonesia when conducting digital diplomacy.

\section{RESULT AND DISCUSSION}

\subsection{Research Data - Interview}

Mrs. Siti Sofia Sudarma, director of information and media of the Ministry of Foreign Affairs of the Republic of Indonesia reveals that conventional diplomacy is accompanied by digital diplomacy and works in line with each other. To accomplish this goal, the Ministry of Foreign Affairs implements a basic communication principle towards their digital diplomacy, which is to listen connect and communicate. This notion is supported by former Sesparlu director Odo Manuhutu, whose training program for senior diplomats focuses heavily on digital diplomacy and the enhancement of digital literacy overall. He highlights that diplomats need to be aware and use digital technology that is available today; professionalism and adaptability are synonymous to each other. Where there is a clear benefit of the internet providing a platform to allow for two-way communication, the future lies in paying attention to artificial intelligence, allowing to anticipate questions asked by the public and respond accordingly[6], which is increasingly explored in contemporary research of big data[18], [19] and in the realm of public relations.[7], [13]

\subsection{Twitter Analytic Data}

All data gathered using Twitter analytic tools were validated on June $8^{\text {th }} 2016$. @portal_kemlu_RI's twitter followers are predominantly male with 65\%. The top demography of twitter followers are based in Indonesia, followed by $1 \%$ based in the United States and less than $1 \%$ based in Australia and Malaysia. Top interests of these users are business and news.

Table 1. Analytical data of @ portal_kemlu_RI (8 June 2016).

\begin{tabular}{ll}
\hline Total followers & 64.129 \\
\hline Gender & $65 \%$ Male \& 35\% Female \\
\hline Language of followers & $97 \%$ English, 3\% Spanish, 1\% Arabic, 1\% Japanese, 1\% Korean \\
\hline Demography: & Indonesia: 92\%, 1\% United States, <1\% Australia, <1\% Malaysia \\
\hline Top interest: & Business \& News \\
\hline
\end{tabular}




\subsection{Twitter Content Data}

From November 2015 to January 2016, there are 133 Tweets that are related to the ASEAN community, with a total impression of $290.118,5.655$ engagement and 1.053 retweets.

Table 2. Frequency of tweets, impressions, engagements and re-tweets.

\begin{tabular}{lrrrrr}
\hline & $\begin{array}{l}\text { Total Tweet } \\
\text { per Month }\end{array}$ & Impressions & Engagements & Re-Tweets & \\
\hline November 2015 & 41 & 111.287 & 3.698 & 433 \\
\hline December 2015 & 70 & 127.693 & 1.236 & 446 \\
\hline January2016 & 24 & 52.767 & 741 & 174 \\
\hline TOTAL & 135 & 291.747 & 5.675 & 1.053 \\
\hline
\end{tabular}

\subsection{Frequency of tweets per month, impressions, engagements and re-tweets}

Frequency of tweets rise in the month of December, as do impressions and re-tweets. Engagements with tweets in November 2015 are higher than in December 2015.Impressions of tweets.

Top impressions are achieved November 2015 and January 2016, the top five tweets are a mixture of knowledge management, information management and disaster management, 4 out of the top 5 being in the English language. 4 out of the top 5 include the mention of a person or an institution with the ' $@$ ' sign. 3 out of 5 tweets include the mention of President Joko Widodo. 4 out of the top 5 include a link to an external source.

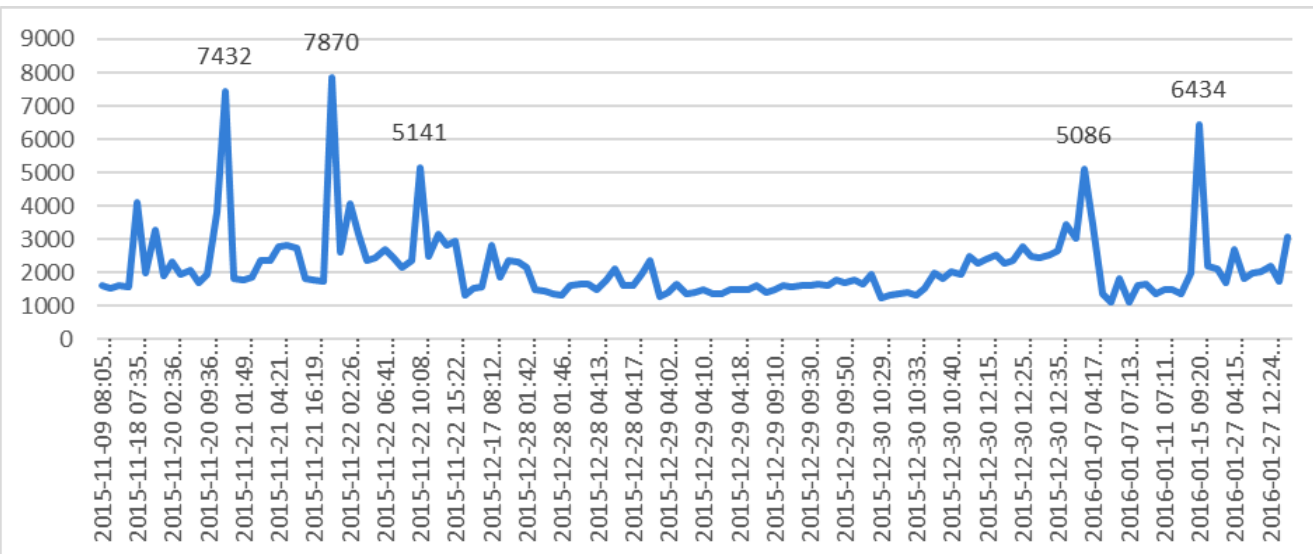

Figure 1.Impressions per ASEAN community related tweets by Indonesia's Ministry of Foreign Affairs - Nov 2015- Jan 2018. 
Table 3. 5 Top tweets by impressions.

\begin{tabular}{|c|c|c|c|c|}
\hline Tweets (Text) & Language & Category & Date Posted & Impressions \\
\hline 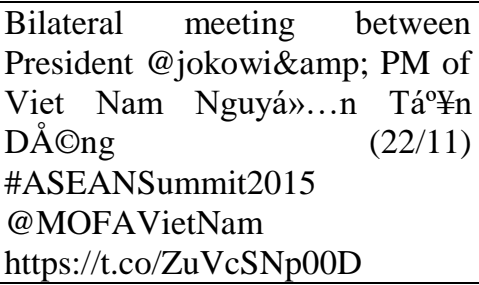 & $\mathrm{E}$ & $\begin{array}{l}\text { Knowledge } \\
\text { Management }\end{array}$ & $\begin{array}{l}12 \\
\text { November } \\
2015\end{array}$ & 7.870 \\
\hline $\begin{array}{l}\text { Presiden RI@jokowibersamaIbu } \\
\text { Negara } \\
\text { @irianajokowihadiripembukaan } \\
\text { KTT ke-27 ASEAN } \\
\text { \#ASEANSummit2015 }\end{array}$ & ID & $\begin{array}{l}\text { Information } \\
\text { Management }\end{array}$ & $\begin{array}{l}21 \\
\text { November } \\
2015\end{array}$ & 7.432 \\
\hline $\begin{array}{l}\text { ASEAN Foreign Minister's } \\
\text { Statement on the Terrorist Attack } \\
\text { in } \\
\text { https://t.co/1Hie4VF81N } \\
\text { https://t.co/MncTPYjz7x }\end{array}$ & $\mathrm{E}$ & $\begin{array}{l}\text { Disaster } \\
\text { Management }\end{array}$ & $\begin{array}{l}15 \text { January } \\
2016\end{array}$ & 6.434 \\
\hline $\begin{array}{l}\text { President@jokowi held bilateral } \\
\text { meeting with @UN SecGen Ban } \\
\text { Ki-Moon on the sidelines of } \\
\text { \#ASEANSummit } 2015 \\
\text { https://t.co/vMq7mIOoww }\end{array}$ & $\mathrm{E}$ & $\begin{array}{l}\text { Knowledge } \\
\text { Management }\end{array}$ & $\begin{array}{l}22 \\
\text { November } \\
2015\end{array}$ & 5.141 \\
\hline $\begin{array}{l}\text { Happy New Year to Our } \\
\text { @ ASEAN } \\
\text { https://t.co/iczS2KBP3w }\end{array}$ & $\mathrm{E}$ & $\begin{array}{l}\text { Information } \\
\text { Management }\end{array}$ & $\begin{array}{l}1 \text { January } \\
2016\end{array}$ & 5.086 \\
\hline
\end{tabular}

\subsection{Tweets by engagement}

Top engagement is achieved in November 2015 and January 2016. 4 out of the five tweets are categorized as information management, 1 as knowledge management, 3 out of the top 5 being in the English language. 4 out of the top 5 include the mention of a person or an institution with the '@' sign. 3 out of 5 tweets include the mention of President Joko Widodo. All top 5 tweets include a link to an external source. 


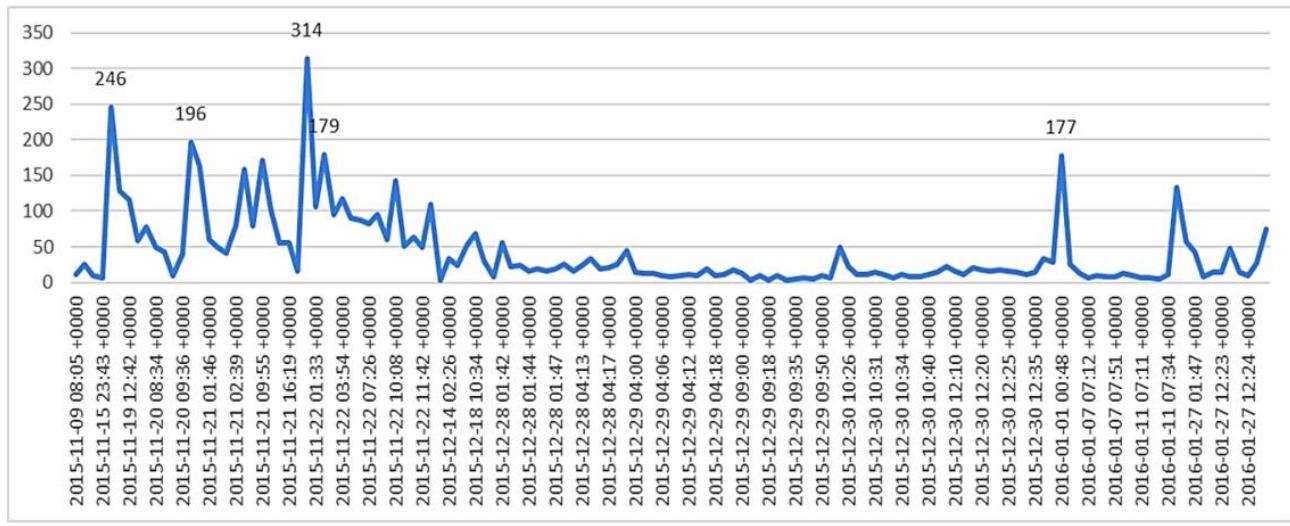

Figure 2. Engagement per ASEAN community related tweets by Indonesia's Ministry of Foreign Affairs - Nov 2015 - Jan 2018.

Table 4. 5 Top tweets by engagement.

\begin{tabular}{|c|c|c|c|c|}
\hline Tweets (Text) & Language & Category & Date Posted & Engagement \\
\hline $\begin{array}{l}\text { Bilateral meeting between } \\
\text { President @ jokowi\&amp; PM } \\
\text { of Viet Nam Nguyá»...n Táo¥n } \\
\text { DÅ@ng } \\
\text { \#ASEANSummit2015 } \\
\text { @MOFAVietNam } \\
\text { https://t.co/ZuVcSNp00D }\end{array}$ & $\mathrm{E}$ & $\begin{array}{l}\text { Knowledge } \\
\text { Management }\end{array}$ & $\begin{array}{l}12 \text { November } \\
2015\end{array}$ & 314 \\
\hline \begin{tabular}{lrr} 
Selamat! & \multicolumn{2}{r}{ SepuluhRibuDolar } \\
AS UntukPemenang @ ASEAN \\
People's & Award \&amp; \\
Founder & $@$ STIKOMLSPR \\
Prita & Kemal & Gani \\
https://t.co/ZiIsPSDwas & \\
\end{tabular} & ID & $\begin{array}{l}\text { Information } \\
\text { Management }\end{array}$ & $\begin{array}{l}18 \text { November } \\
2015\end{array}$ & 246 \\
\hline $\begin{array}{l}\text { Presiden RI, Joko Widodo, tiba } \\
\text { di Kuala Lumpur untukhadiri } \\
\text { KTT ke-27 ASEAN } \\
\text { \#ASEANSummit2015 } \\
\text { https://t.co/ZZDeLVMZdS } \\
\end{array}$ & ID & $\begin{array}{l}\text { Information } \\
\text { Management }\end{array}$ & $\begin{array}{l}20 \text { November } \\
2015\end{array}$ & 196 \\
\hline $\begin{array}{l}\text { Bilateral Meeting between } \\
\text { President @ jokowi and PM of } \\
\text { Japan @AbeShinzo on the } \\
\text { sidelines } \\
\text { \#ASEANSummit2015 } \\
\text { https://t.co/e0pZWdEt29 }\end{array}$ & $\mathrm{E}$ & $\begin{array}{l}\text { Information } \\
\text { Management }\end{array}$ & $\begin{array}{l}22 \text { November } \\
2015\end{array}$ & 179 \\
\hline \begin{tabular}{lll} 
Happy New Year to Our \\
@ ASEAN & \multicolumn{1}{c}{ Family!! } \\
https://t.co/iczS2KBP3w
\end{tabular} & $\mathrm{E}$ & $\begin{array}{l}\text { Information } \\
\text { Management }\end{array}$ & $\begin{array}{ll}1 & \text { January } \\
2016 & \end{array}$ & 177 \\
\hline
\end{tabular}




\subsection{Categories of tweets and language}

135 tweets only address 4 out of the 8 existing transformational diplomacy categories. $8 \%$ of total tweets are categorized as knowledge management and another $8 \%$ as public diplomacy. Information management amounts to the highest number of tweets at $83 \%$ and disaster response with less than 1\%. Tweets are made interchangeably in English, as well as Indonesian language, with Indonesian language being predominant.

Table 5. Number of categories of tweets in relation to transformative goals of diplomacy.

\begin{tabular}{|c|c|c|c|c|}
\hline Tweets (Text) & $\begin{array}{c}\text { Categories of } \\
\text { Tweets }\end{array}$ & $\begin{array}{l}\text { Number } \\
\text { of Tweets }\end{array}$ & $\begin{array}{c}\text { Indonesian } \\
\text { Language }\end{array}$ & $\begin{array}{c}\text { English } \\
\text { Language }\end{array}$ \\
\hline $\begin{array}{l}\text { President@jokowi held bilateral } \\
\text { meeting with @UN SecGen Ban } \\
\text { Ki-Moon on the sidelines of } \\
\text { \#ASEANSummit } 2015\end{array}$ & $\begin{array}{l}\text { Knowledge } \\
\text { Management }\end{array}$ & $11(8 \%)$ & 3 & 7 \\
\hline $\begin{array}{l}\text { This year is an important year for } \\
\text { ASEAN as it enters the ASEAN } \\
\text { Community and in preparation } \\
\text { for ASEAN } 2025 \text {. }\end{array}$ & $\begin{array}{c}\text { Public } \\
\text { Diplomacy }\end{array}$ & $11(8 \%)$ & 8 & 3 \\
\hline $\begin{array}{l}\text { \#ASCC is focusing on increasing } \\
\text { the involvement of myriad of } \\
\text { stakeholders, to deepen the WE } \\
\text { feeling among \#ASEANPeoples } \\
\text { \#ASEANisUs }\end{array}$ & $\begin{array}{l}\text { Information } \\
\text { Management }\end{array}$ & $\begin{array}{c}112 \\
(83 \%)\end{array}$ & 68 & 44 \\
\hline $\begin{array}{l}\text { ASEAN Foreign Minister's } \\
\text { Statement on the Terrorist Attack } \\
\text { in } \\
\text { https://t.co/1Hie4VF81N } \\
\text { https://t.co/MncTPYjz7x }\end{array}$ & $\begin{array}{l}\text { Disaster } \\
\text { Response }\end{array}$ & $1(<1 \%)$ & 0 & 1 \\
\hline
\end{tabular}

According to the interview with Mrs.Siti Sofia Sudarma, the goals of Indonesia's Ministry of Foreign Affair's digital diplomacy are to shape public opinion, inform and educate public about foreign policy. This statement indicates an intent to foster two-way communication between the government and the public, asymmetrically as well as symmetrically. The intention of Indonesia's Ministry of Foreign Affairs is to apply two-way communication through listening, connecting and communicating. Connecting and communicating can be pinpointed through tags and mentions, however 'listening' insinuates a response to an issue, which is not evident in any of the 135 tweets regarding the topic of the ASEAN community.

The Indonesian Ministry of Foreign Affairs carries out conventional diplomacy and digital diplomacysimultaneously, which can be seen by consistent references to actual physical events and activities. In this sense, their objective to inform and educate the public about foreign policy is evident. @portal_kemlu_RI showcases cooperation with other directorate and institutions through consistent tagging and shares of links of existing websites, posters and blogs. The content of the tweets collected from November 2015 until January 2016 reveal that most tweets are categorized as information managementwith staggering $83 \%$, followed by a far stretch with knowledge management and public diplomacy at $8 \%$ and disaster response by 
less than $1 \%$.Unsurprisingly, Indonesian language is predominantly used, however with the launch of the ASEAN community, frequency of tweets, as well as the use of English language increases during December 2015. Simultaneously, the use of the English language increases, demonstrating an intent to actively share information with the international community.

In a broader sense the Indonesian Ministry of Foreign Affairs is building its two-way communication through social media, whilst simultaneously maintaining their conventional methods. However, as transformative goals of digital diplomacy depend also on consular communications, internet freedom, external resources and policy planning - the absence of these categories impacts on the effective public relations of the ASEAN community, as social media integration is not harnessing effectively the opportunity to 'listen' and receive desired feedback by the public. Exposure, feedback, engagement (connecting) and exchange (sharing) are required to create major changes to implore public diplomacy.[15]Connections are made in $17 \%$ of tweets, which are directed to another person or institution through the '@' sign. The majority of these mentions include the account of Indonesian President Joko Widodo with '@jokowi', followed by mentions of international Heads of States and other relevant organizational bodies. It makes sense that the topic of the ASEAN community is socialized to Indonesians by showcasing Indonesia's active involvement through its own president.

\section{CONCLUSION}

In conclusion, digital diplomacy is a new approach of doing diplomatic communication. It is a complementary of conventional diplomacy, which mediated through Internet and social media platform. The Indonesian Ministry of Foreign Affairs is aware of applying a diplomatic approach to maintain and support the conventional diplomacy.

The Indonesian Ministry of Foreign Affairs should continue their efforts in employing social media integration more rigorously by connecting with the international community with the use of English language and by mentioning more frequently relevant individuals, as well as institutions with the '@' sign. The demographics and interests of the audience can be more actively addressed by linking ASEAN community topics with the fields of business and current affairs, in order to stimulate increased engagement.

Based on the intent to create public diplomacy and the data-set, and evaluation of the consistency of impressions and engagements, two-way asymmetrical communication is already in place. A deeper insight in the actual engagement content reveals however that twoway symmetrical communication in line with a social media integration model requires an active call for opinions also. Engagement levels through re-tweets are consistent, the first steps towards a symmetrical model are underway.

Potential future research has the potential to reveal interesting insights by comparing a new data set on the topic of the ASEAN community with the data provided in this research. A complete implementation of the social media integration model, as well as all 8 transformational diplomatic goals can be truly transformational in terms of level of engagement and effective public relations. Future training of Sesparlu members will benefit from research of big data on citizen's sentiments, providing a strong foundation for a unitedstrategy in responsiveness of the Indonesian Ministry of Foreign Affairs; and with that, an effective platform for two-way communication. 


\section{REFERENCES}

[1] A. Sandre, Twitter for Diplomats. Geneva, Rome: DiploFoundatio and Istituto Diplomatico, 2013.

[2] A. Taleb, C. Ratiu, and R. Molz, "Corporate Diplomacy and Institutional Upheaval in Host Countries: The 'Arab Spring' Experience of Two Canadian Multinationals in Egypt," in International Business Diplomacy, Emerald Publishing Limited, 2017, pp. 241-264.

[3] B. J. Hurn, "The role of cultural diplomacy in nation branding," Ind. Commer. Train., vol. 48, no. 2, pp. 80-85, Feb. 2016.

[4] M. Z. Rakhmat, “The Dark Side of Indonesia's Social Media Boom," The Diplomat, 2017. [Online]. Available: https://thediplomat.com/2017/05/the-dark-side-ofindonesias-social-media-boom/.

[5] S. Pohan, H. Pohan, and I. Nuria Savitri, "Digital Diplomacy-Maximizing Social Media in Indonesia's Economic and Cultural Diplomacy," in Proceedings of the 1st International Conference on Social and Political Development (ICOSOP 2016), 2017, vol. 2, no. 2, p. 20.

[6] The Australia-Indonesia Centre, "In Conversation with Odo Manuhutu - Director of Sesparlu - YouTube," The Australia-Indonesia Centre, 2018. [Online]. Available: https://australiaindonesiacentre.org/conversation-odo-manuhutu-director-sesparlu/.

[7] L. Dahlberg, "Re-constructing digital democracy: An outline of four "positions," New Media Soc., vol. 13, no. 6, pp. 855-872, Sep. 2011.

[8] I. Irwansyah, "Border Issue: Misperception between Indonesia and Malaysia," SHS Web Conf., vol. 33, p. 58, Feb. 2017.

[9] B. J. Hurn, "The role of cultural diplomacy in nation branding," Ind. Commer. Train., vol. 48, no. 2, pp. 80-85, Feb. 2016.

[10] Public Relations Society of America, "Public relations defined: A modern definition for the new era of public relations," Public Relations Society of America, 2012. [Online]. Available: http://prdefinition.prsa.org/index.php/2012/04/11/the-moderndefinition-of-public-relations/.

[11] Sheany, "Indonesia Goes Up on 2018 Henley Passport Index," Jakarta Globe, 2018. [Online]. Available: https://jakartaglobe.id/news/indonesia-goes-2018-henleypassport-index/.

[12] Henley \& Partners, "Henley Passport Index 2006 to 2018," Henley Passport Index, 2018. [Online]. Available: https://www.henleypassportindex.com/.

[13] J. E. Grunig and L. A. Grunig, "Conceptual differences in public relations and marketing: The case of health-care organizations," Public Relat. Rev., vol. 17, no. 3, pp. 257-278, Sep. 1991.

[14] W. T. Coombs and S. J. Holladay, Eds., The Handbook of Crisis Communication. Oxford, UK: Wiley-Blackwell, 2010.

[15] I. Garcia, "Social Media-Integration-Theory-Model," Social Media Today, 2011. [Online]. Available: https://www.socialmediatoday.com/content/social-mediaintegration-theory-model.

[16] Technische Universitaet Ilmenau, "What is Public Diplomacy?," Technische Universitaet Ilmenau, 2018. .

[17] F. Hanson, "Revolution@State: the spread of ediplomacy," Lowy Institute, 2012. 
[Online]. Available: https://www.brookings.edu/research/revolution-state-the-spreadof-ediplomacy/.

[18] H. Schoen, D. Gayo-Avello, P. T. Metaxas, E. Mustafaraj, M. Strohmaier, and P. Gloor, "The power of prediction with social media," Internet Res., vol. 23, no. 5, pp. 528-543, 2013.

[19] Y. Lee and H. Chun, "Nation image and its dynamic changes in Wikipedia," Asia Pacific J. Innov. Entrep., vol. 11, no. 1, pp. 38-49, Apr. 2017. 